\title{
Calcium Levels in the Maxillae of Human Foetuses
}

\author{
Niveles de Calcio en los Maxilares de Fetos Humanos
}

"Ghaus Farah; **Faruqi, N. A; ***Khan, H. S. \& *Kirmani, F.

\begin{abstract}
FARAH, G.; FARUQI, N. A.; KHAN, H. S. \& KIRMANI. F. Calcium levels in the maxillae of human foetuses. Int. J. Morphol., 29(1):268-271, 2011.

SUMMARY: Calcium along with phosphorus and carbonate imparts hardness and strength to skeletal system. Most of the human studies in this context are based on informations in postnatal life. There are different theories to explain the manner in which the matrix of bone becomes impregnated with the two inorganic salts, calcium phosphate and calcium carbonate. In our study, 29 human foetuses were obtained from the museum section of Department of Anatomy, J .N. Medical College, Aligarh, and divided into five groups. Maxillae were cleaned by separating the soft tissue and dissolved in concentrated nitric acid to determine calcium. Results were analysed by using Student's ' $t$ ' test. The most striking feature of our findings was a reduction in aforementioned relative calcium in subsequent groups of foetuses. This decrease was highly significant in foetuses of last three groups i.e. III, IV and V. On the other hand, when total amount of calcium in foetal maxillae of adjacent groups were compared, a steady rise in concentration of calcium was noticed but no definite pattern was observed. Sexual dimorphism could be considered only in groups IV and V foetuses due to lack of female foetuses in first three groups. Some scientists did consider the human foetal bones but their interests were confined to parietal bone, femur and teeth. None of the earlier studies considered calcium concentration in maxillae of human foetuses. Therefore, our study aimed at measuring the level of calcium in maxillae of developing human foetuses in different age groups to find pattern, if any, during development for medicolegal purposes.
\end{abstract}

KEY WORDS: Calcium; Foetus; Maxilla; Development; Facial Skeleton.

\section{INTRODUCTION}

The most abundant mineral in the body is calcium which accounts for almost $99.9 \%$ of the total body stores. Calcium imparts hardness and strength to the skeletal system. During final trimester of pregnancy, about 200 to $300 \mathrm{mg}$ of calcium is deposited daily in the skeleton of the developing human foetus. Controversy exists regarding mechanism involved in precipitation of calcium salts in different bones (Watt, 1923). Very little is known about preferential deposition or exact amount of calcium precipitated in different bones. Most of the literature regarding bodily calcium are based on experimental studies on lower mammals (Chan \& Swaminathan, 1998; Feaster et al., 1956; Graham \& Scothorme, 1970). Most of the human studies on calcium are based on information in postnatal life. GoretNicaise \& Dhem (1985) compared the calcium content in different tissues of human mandible. Tzaphildou \& Zaichik (2003) measured the calcium,phosphorus, calciumphosphorus ratio in rib bone of healthy humans. Fischer $e t$ al. (2009) found concentrations of metals including calcium in maxilla and mandible, deciduous and permanent human teeth. Some scientists did consider the human foetal bone but their interests were confined to parietal bone (Yoshida, 1930 cited by Macdonald, 1954; Toverud \& Toverud, 1933; Sliwonik, 2002), femur (Mokrzynski, 1994) and teeth (Tobin, 1972; Deutsh \& Pe' er, 1982). None of the earlier studies considered maxillary calcium concentration in human foetuses. Organic materials disappear but the minerals persist for long time after death. Accurate knowledge of calcium, phosphorus and carbonate will help in determining the age of foetuses which will be of great medicolegal importance.

\footnotetext{
* Lecturer, Department of Anatomy, J. N. Medical College, Aligarh Muslim University, India.

** Professor, Department of Anatomy, J. N. Medical College, Aligarh Muslim University, India.

**** Professor, Department of Medicine, J. N. Medical College, Aligarh Muslim University, India.
} 


\section{MATERIAL AND METHOD}

Twenty nine human foetuses were collected from the Departmental Museum of Anatomy, J. N. Medical College, A.M.U., Aligarh. Research works on these foetuses are already in progress, the permission for which had already been sought from the ethical committee of the institution by the postgraduate students of the Department of Anatomy. The aforementioned foetuses were divided into five groups (Table I). Each foetal head was divided into two halves by midsagittal section. Maxillae were cleaned, demarcated from adjacent bones and then removed. Each maxilla was weighed and dissolved in $5 \mathrm{ml}$ of concentrated nitric acid. Solutions were filtered through Whatman number 1 filter paper. The solutions thus obtained were used to measure the calcium by the method of Henry \& Dryer (1963). Results were analysed by using Student's ' $t$ ' test.

\section{RESULTS AND DISCUSSION}

A wealth of literature starting from early nineteenth century (Watt) till date (Feaster; Fischer et al.) could not yet solve the manner in which the matrix of a bone becomes impregnated with calcium. Our study on calcium concentration in foetal maxillae reflects some light regarding pattern of impregnation rather than mechanism. Maxilla is one of the bones like clavicle and other skull bones in which ossification is earliest to appear i.e. at $26^{\text {th }}$ day of gestation (Graham \& Scothorne). Since in our study all the foetuses were of more than 14 weeks of intrauterine life, good amount of calcium were expected in all the maxillae. In the first group of foetuses of less than 17 weeks of intrauterine life, the mean value of calcium was found to be $18.9 \mathrm{mg} / \mathrm{g}$ of dry weight of maxilla (Table II). The most striking feature of our findings is a reduction in aforementioned relative calcium in subsequent groups of foetuses. This decrease was highly significant in groups
III, IV and V foetuses (Table II), so much so that in the last group, concentration of calcium came down to $1.51 \mathrm{mg} / \mathrm{g}$ of maxilla. This was a clear indication of relatively marked increase in matrix formation in maxilla than the rate of mineralization. On the other hand, when total amount of calcium in foetal maxillae of adjacent groups were compared, a steady rise in concentration of calcium was noticed but no definite pattern was observed (Table III). Though significant rise of total calcium level was very little (only 8 per cent) in groups II and III, there was no change in the concentration in group IV. A steep rise (about 41 per cent) in calcium level was observed in group V. Increase in the calcium level in absolute term with age in foetal parietal bone was reported by Sliwonik (2002) and that in foetal femur by Mokrzynski. Yoshida and Toverud \& Toverud for the first time made an observation on variable change in calcium concentration of foetal parietal bone by comparing absolute value with percentage. Changes in absolute values of calcium concentration conformed with our findings but the increase in percentage of calcium was in contrast to our readings. The relative importance of parietal bone to protect the brain might explain the reason. Toverud \& Toverud (1933) found a sudden increase in calcium concentration in the section of parietal bone of full term babies. The finding supports the steep rise in calcium concentration in maxillae of group $\mathrm{V}$ foetuses.

Bilateral variations (Table IV and V) and sexual dimorphism (Table VI and VII) could not be ascertained in the calcium concentrations of foetal maxillae statistically. Sexual dimorphism could be considered only in group IV and $\mathrm{V}$ foetuses due to lack of female foetuses in first three groups.

Determination of phosphorus, calcium phosphorus ratio, calcium phosphate and calcium carbonate in the foetal maxillae in future will provide better insight to our study.

Table I. Subgrouping of human foetuses.

\begin{tabular}{cccccccc}
\hline \multirow{2}{*}{ Groups } & Age (wks) & \multicolumn{3}{c}{ Number of foetuses } & \multicolumn{3}{c}{ Number of maxillae } \\
\cline { 3 - 7 } & & Total & Male & Female & Total & Male & Female \\
\hline I & $<17$ wks & 6 & 6 & Nil & 11 & 11 & Nil \\
II & $17-20$ & 7 & 7 & Nil & 13 & 13 & Nil \\
III & $21-25$ & 7 & 7 & Nil & 13 & 13 & Nil \\
IV & $26-30$ & 6 & 4 & 2 & 11 & 7 & 4 \\
V & $>30$ & 3 & 1 & 2 & 5 & 2 & 3 \\
\hline
\end{tabular}


FARAH, G.; FARUQI, N. A.; KHAN, H. S. \& KIRMANI. F. Calcium levels in the maxillae of human foetuses. Int. J. Morphol., 29(I):268-271, 2011.

Table II. Calcium levels in foetal maxillae ( $\mathrm{mg} / \mathrm{g}$ of dry bone).

\begin{tabular}{lcrcc}
\hline Groups & $\mathrm{n}$ of case & Mean $\pm \mathrm{SD}$ & $\%$ change & P value \\
& & & & \\
\hline I & 11 & $18.90 \pm 8.22$ & & \\
II & 13 & $18.00 \pm 7.37$ & -5 & $<0.8$ \\
III & 13 & $6.64 \pm 4.17$ & -63 & $<0.001$ \\
IV & 11 & $2.28 \pm 0.59$ & -66 & $<0.002$ \\
V & 5 & $1.51 \pm 0.36$ & -34 & $<0.02$ \\
\hline
\end{tabular}

Table III. Total calcium in foetal maxillae (mg of dry bone).

\begin{tabular}{lcccc}
\hline Groups & $\mathrm{n}$ of case $\mathrm{M}$ & Mean $\pm \mathrm{SD}$ & \% change & P value \\
\hline I & 11 & $0.80 \pm 0.074$ & & \\
II & 13 & $0.87 \pm 0.071$ & +8 & $<0.04$ \\
III & 13 & $0.92 \pm 0.054$ & +8 & $<0.03$ \\
IV & 11 & $0.93 \pm 0.063$ & +0.32 & $<0.6$ \\
V & 5 & $1.31 \pm 0.045$ & +41 & $<0.05$ \\
\hline
\end{tabular}

Table IV. Bilateral variations in calcium levels $(\mathrm{mg} / \mathrm{g})$ of foetal maxillae.

\begin{tabular}{|c|c|c|c|c|c|c|}
\hline \multirow[t]{2}{*}{ Groups } & \multicolumn{2}{|c|}{ Right side } & \multicolumn{2}{|c|}{ Left side } & \multirow[t]{2}{*}{$\%$ difference } & \multirow{2}{*}{$\begin{array}{l}\mathrm{P} \\
\text { Value }\end{array}$} \\
\hline & $\mathrm{n}$ maxillae & Mean \pm SD & $\mathrm{n}$ maxillae & Mean \pm SD & & \\
\hline $\mathrm{I}$ & 6 & $18.0 \pm 9.18$ & 5 & $21.8 \pm 8.71$ & 17 & $<0.5$ \\
\hline II & 6 & $15.10 \pm 7.81$ & 7 & $16.8 \pm 4.15$ & 10 & $<0.7$ \\
\hline III & 7 & $7.48 \pm 4.09$ & 6 & $6.28 \pm 4.62$ & 16 & $<0.6$ \\
\hline IV & 6 & $2.24 \pm 0.68$ & 5 & $2.32 \pm 0.56$ & 3 & $<0.8$ \\
\hline V & 2 & $1.35 \pm 0.39$ & 3 & $1.49 \pm 0.47$ & 9 & $<0.2$ \\
\hline
\end{tabular}

Table V. Bilateral variations in total amounts of calcium $(\mathrm{mg})$ of foetal maxillae.

\begin{tabular}{lcccccc}
\hline Groups & \multicolumn{2}{c}{ Right side } & \multicolumn{2}{c}{ Left side } & \% difference & P Value \\
\cline { 2 - 5 } & $\mathrm{n}$ maxillae & Mean \pm SD & n maxillae & Mean \pm SD & & \\
\hline I & 6 & $0.87 \pm 0.17$ & 5 & $0.85 \pm 0.10$ & 2 & $<0.8$ \\
II & 6 & $0.85 \pm 0.050$ & 7 & $0.91 \pm 0.10$ & 7 & $<0.2$ \\
III & 7 & $0.94 \pm 0.025$ & 6 & $0.95 \pm 0.042$ & 1 & $<0.8$ \\
IV & 6 & $0.99 \pm 0.037$ & 5 & $0.97 \pm 0.15$ & 2 & $<0.8$ \\
V & 2 & $1.40 \pm 0.41$ & 3 & $1.18 \pm 0.22$ & 19 & $<0.05$ \\
\hline
\end{tabular}

Table VI. Sexual dimorphism in calcium levels $(\mathrm{mg} / \mathrm{g})$ of foetal maxillae.

\begin{tabular}{ccccccc}
\hline Groups & \multicolumn{2}{c}{ Male foetuses } & \multicolumn{2}{c}{ Female foetuse } & \% difference & P Value \\
\cline { 2 - 5 } & n maxillae & Mean \pm SD & n maxillae & Mean \pm SD & & \\
\cline { 1 - 5 }$I V$ & 7 & $2.30 \pm 0.73$ & 4 & $2.25 \pm 0.35$ & 2 & $<0.7$ \\
$V$ & 3 & $1.37 \pm 0.44$ & 2 & $1.46 \pm 0.45$ & 7 & $<0.8$ \\
\hline
\end{tabular}

Table VII. Sexual dimorphism in total amounts of calcium of foetal maxillae (mg).

\begin{tabular}{|c|c|c|c|c|c|c|}
\hline \multirow[t]{2}{*}{ Groups } & \multicolumn{2}{|c|}{ Male foetuses } & \multicolumn{2}{|c|}{ Female foetuses } & \multirow{2}{*}{$\begin{array}{c}\% \\
\text { difference }\end{array}$} & \multirow[t]{2}{*}{ P Value } \\
\hline & n maxillae & Mean \pm SD & $\mathrm{n}$ maxillae & Mean \pm SD & & \\
\hline$I V$ & 7 & $1.11 \pm 0.33$ & 4 & $1.04 \pm 0.14$ & 6 & $<0.7$ \\
\hline$V$ & 3 & $1.46 \pm 0.34$ & 2 & $1.63 \pm 0.14$ & 12 & $<0.2$ \\
\hline
\end{tabular}


FARAH, G.; FARUQI, N. A.; KHAN, H. S. \& KIRMANI. F. Niveles de calcio en los maxilares de fetos humanos. Int. J. Morphol., 29(1):2678$271,2011$.

RESUMEN: El calcio junto con el fósforo y el carbonato otorgan la dureza y la fuerza al sistema esquelético. La mayoría de los estudios en seres humanos se basan en la información de la vida postnatal. Existen diferentes teorías para explicar la manera en que la matriz del hueso se impregna con las de sales inorgánicas, fosfato de calcio y carbonato de calcio. Fueron utilizados 29 fetos humanos del Museo del Departamento de Anatomía, Facultad J. N. Medical, Aligarh, divididos en cinco grupos. Los maxilares fueron limpiados separando los tejidos blandos, luego se disolvieron en ácido nítrico concentrado para determinar el nivel de calcio. Los resultados se analizaron a través de la prueba t de Student. La característica más notable fue la reducción de calcio en los grupos subsecuentes de los fetos. Esta disminución fue muy significativa en los fetos de los tres últimos grupos es decir, III, IV y V. Por otro lado, cuando se comparó la cantidad total de calcio en maxilares fetales de los grupos adyacentes, se observó un aumento constante en la concentración de calcio, sin ningún patrón definido. El dimorfismo sexual pudo ser considerado sólo en los grupos IV y V de los fetos, ya que la falta de fetos femeninos en los primeros tres grupos impidió su comparación. Algunos científicos han examinado los huesos del feto humano, pero sus intereses se limitan a los huesos parietales, al fémur y los dientes. Ningún de los primeros estudios considera la concentración de calcio en los maxilares de los fetos humanos. Así el objetivo de este estudio fue medir el nivel de calcio durante desarrollo de fetos humanos en maxilares de fetos de diferentes edades para determinar algún patrón, si los hubiera, con fines médico-legales.

PALABRAS CLAVE: Calcio; Feto; Maxilar; Desarrollo; Esqueleto facial.

\section{REFERENCES}

Chan, E. L. \& Swaminathan, R. Calcium metabolism and bone calcium content in normal and oophorectomized rats consuming various levels of saline for 12 months. J. Nutr., 128:633-9, 1998.

Deutsch, D. \& Pe'er, E. Development of enamel in human fetal teeth. J. Dent. Res., 1543-51, 1982.

Feaster, J. P.; Hansard, S. L.; Outler, J. C. \& Davis, G. K. Placental transfer of calcium in the rat. J. Nutr., 58:399406, 1956.

Fischer, A.; Wiechu?a, D.; Postek-Stefan'ska, L. \& Kwapulin'ski, J. Concentrations of Metals in Maxilla and Mandible Deciduous and Permanent Human Teeth. Biol. Trace Elem. Res., Epub ahead of print, 2009.

Goret-Nicaise, M. \& Dhem, A. Comparison of the calcium content of different tissues present in the human mandible. Acta Anat., 124:167-72, 1985.

Graham, R. W. \& Scothorne, R. J. Calcium homeostasis in the foetal guinea pig. Q. J. Exp. Physiol. Cogn. Med. Sci., 55:4453, 1970.

Henry, R. J. \& Dryer, R. L. Standard Methods of Clinical Chemistry. Academic Press, New York, 1963. pp.205-37.

Macdonald, I. Chemical analysis of human foetal skull bones. Biochem, J., 57:437-9, 1954.

Mokrzyn'ski, S. Analysis of mineral composition of femoral bones in the human fetus. Ann. Acad. Med. Stetin., 40:2335, 1994.
Sliwonik, I. Development of parietal bone based on ossification in the fetus. Ann. Acad. Med. Stetin., 48:145-62, 2002.

Tobin, C. E. Correlation of vascularity with mineralization in human fetal teeth. Anat. Rec., 174:371-9, 1972.

Toverud, K. U. \& Toverud, G. Chemical and histological studies of bones and teeth of newborn infants. Acta Paediat., 16:459-67, 1933.

Tzaphlidou, M. \& Zaichick, V. Calcium, phosphorus, calciumphosphorus ratio in rib bone of healthy humans. Biol. Trace Elem. Res., 93:63-74, 2003.

Watt, J. C. The behavior of calcium phosphate and calcium carbonate (bone salts) precipitated in various media, with applications to bone formation. Biological Bulletin, 44:280317, 1923.

\section{Correspondence to: \\ Dr. Ghaus Farah \\ Lecturer \\ Department of Anatomy \\ J. N. Medical College \\ A. M. U. Aligarh, 202002 \\ INDIA}

Telephone: + 91-9319201406 / 9411041594

Email: drfarahghaus@rediffmail.com drfarahghaus@gmail.com

Received: $10-08-2010$

Accepted: 22-11-2010 